ACTA MYCOLOGICA

Vol. 42 (1): 69-73

2007
Dedicated to Professor Alina Skirgietto

on the occasion of her ninety-fifth birthday

\title{
Gloiodon strigosus (Swartz: Fr.) P. Karst. (Bondarzewiaceae) in Poland
}

\author{
ANNA BUJAKIEWICZ \\ Department of Plant Ecology and Environment Protection, Adam Mickiewicz University \\ Umultowska 89, PL-61-614 Poznań, ascom@amu.edu.pl
}

Bujakiewicz A.: Gloiodon strigosus (Swartz: Fr.) P. Karst. (Bondarzewiaceae) in Poland. Acta Mycol. 42 (1):69-73, 2007.

Gloiodon strigosus (Swartz: Fr.) P. Karst. recognized as an extinct species in Poland, has been recently found in the Białowieża National Park. Iconography and synonyms are given and the distribution and ecology is discussed.

Key words: Gloiodon strigosus, Bondarzewiaceae, Russulales, extinct species

\section{INTRODUCTION}

Gloiodon strigosus (Swartz: Fr.) P. Karst., a representative of Bondarzewiaceae family (Kirk et al. 2001), recognized as an extinct species in the Red List of Macrofungi in Poland (Wojew od a, Ław ry nowicz 2006) has been recently found in the Area of Strict Protection of the Białowieża National Park. Fructifications were collected by the author in September 2004 during the mycological excursion devoted to the observation of fruit bodies of a rare and interesting fungus, Rhodotus palmatus which occurs in that area regularly in early autumn, since 2001 (Bujakiewicz 2002b, 2003; Bujakiewicz, Nita 2004).

The locality site is characteristic of dense thickets covering piles of fallen logs of elm (Ulmus scabra) which fell a victim of the Dutch elm disease. The logs are not removed and nourish many rare representatives of plants, animals (insects) and fungi (Bujakiewicz 2002a, b, 2003).

\section{NOMENCLATURE, ICONOGRAPHY AND DRAWINGS}

Hydnum strigosum Swartz, Kongl. Vetensk. Acad. Nva Handl. 31(3): 250, 1810: Fr., Syst. Mycol. 1: 414, 1821; Gloiodon strigosus (Swartz: Fr.) P. Karst., Medd. Soc. F. Fl. Fenn. 5: 42. 1879; Sclerodon strigosus (Swartz: Fr.) Karst., Finl. Basids. 361. 1889.

Nikolajeva (1961) 205-207, Fig. 153-155, Jahn (1979) 75, Fig. 40; Jahn and Sturm (1983), Fig. 1-10; Rym an and Holmåsen (1984): 108; Koski-Kotiranta and Nie melä 1988 (1987): 61-64, Fig. 13-15. 


\section{DESCRIPTION OF COLLECTED MATERIAL}

Fructifications of Gloiodon strigosus were collected on September 18, 2004 in forest section 398 of the Area of Strict Protection of the Białowieża National Park (Fig. 1) along the "didactic trial", on underneath of the log of Ulmus scabra, on

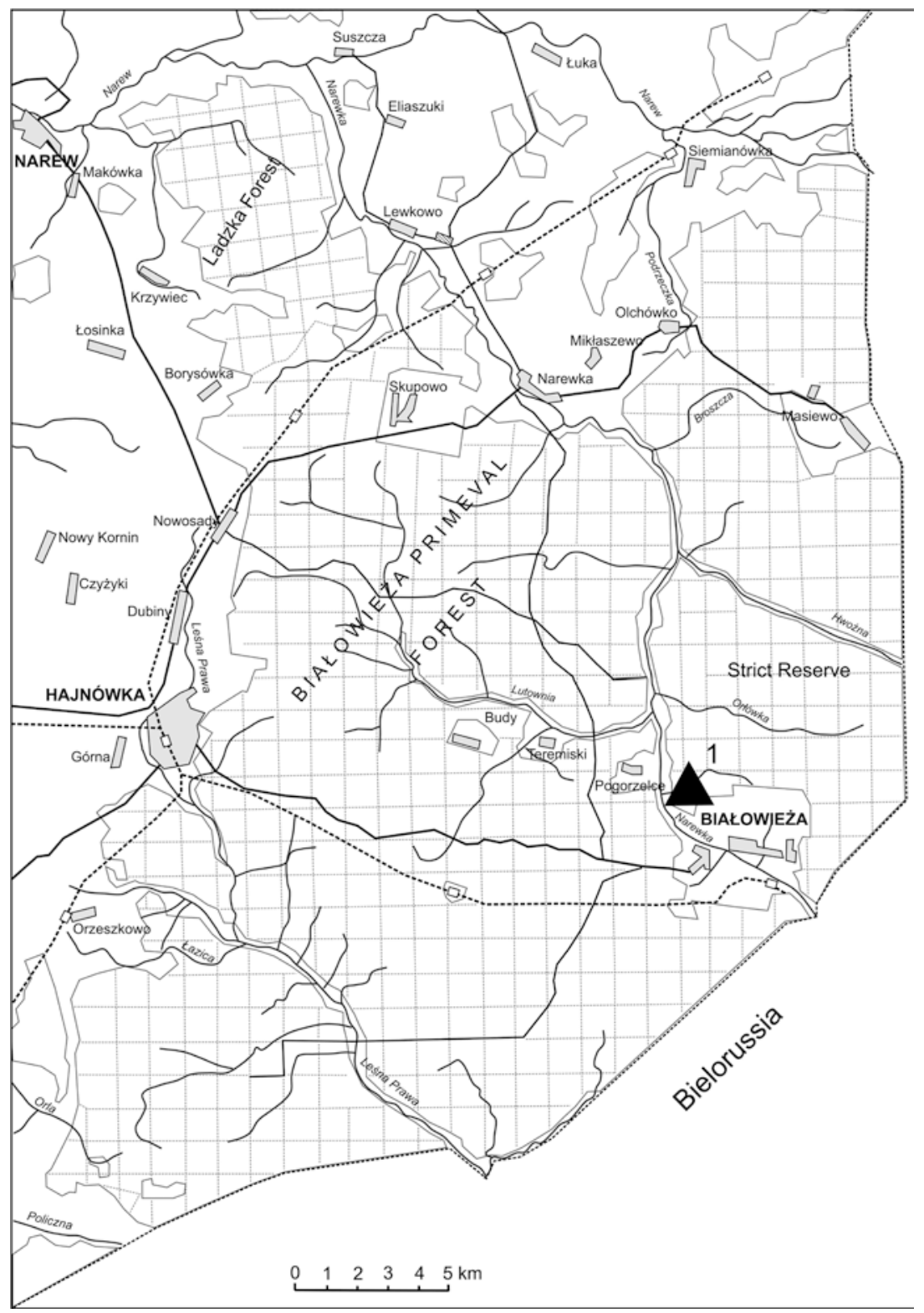

Fig. 1. The Białowieża Forest (acc. to Falińs ki 1986, modified) - distribution of Gloiodon strigosus in the Białowieża Forest.

1-locality in the Area of Strict Protection of the Białowieża National Park (2004). 
decorticated wood in association with Auricularia mesenterica. The fruit body was emerging from remnants of an older one and was mostly fan shaped (Fig. 2). The forest is classified as the phytocoenosis of the Fraxino-Alnetum association with the elements of the Tilio-Carpinetum association.

With regards to morphology and sporulation elements of the fruit bodies specimens collected correspond entirely with Jahn's (1979) photo (Fig. 2) and Jahn and Sturm's (1983) description. Minutely verrucose spores of Gloiodon strigosus seen under the electron microscope are presented on figure 3.

There are three species up to now recognized in the genus Gloiodon: G.occidentale Ginns growing on gymnosperms in North America and having glabrous spores, $G$. nigrescens (Petch) Maas occurring in Sri Lanka, having pileal surface with scattered hairs or even glabrous and $G$. strigosus distinguished by the occurrence on angiosperm wood, having pileal surface densly haired and smaller verrucose spores. (Ginns 1988).

Gloiodon strigosus resembles Auriscalpium vulgare in many characters, both macro-and microscopical and formerly belonged to the Auriscalpiaceae family (Ma s Geester a n u 1963). Now it belongs to Bondarzewiaceae family and represents the order Russulales (Kirk et al. 2001; Wojew od a 2003).

In the literature Gloiodon strigosus is recorded on angiosperms, mostly on Populus, Alnus, Salix and Prunus, seldom is found on Ulmus and Betula (Ko s k i-Kotir a n ta, Niem elä 1988). Nikolajeva (1961) noted some Siberian fructifications collected in Sajan Mts on fir (Abies) which may belonged to G. occidentale.

Gloiodon strigosus is saprotrophic, causes white rot (J a h n 1979) and prefers humid microclimate. It is a rare and endangered species with vulnerable ecology, connected with old, well preserved forests. It's distribution covers the Northern Hemisphere mainly throughout the Boreal zone, both in the interior of the continents and in oceanic areas. The first find of Gloiodon strigosus in Central Europe was announced by Jahn and Sturm (1983) in the Bavarial Alps in an Oroboreal montane zone (Koski-Kotiranta, Niemelä 1988).

\section{DISTRIBUTION}

In Poland: Ladzka Forest in the complex of the Białowieża Primeval Forest, on logs of deciduous trees (Błońs ki 1889); Area of Strict Protection of the Białowieża National Park, forest section 398.

In the world: Scandinavia: Finland, Norway, Sweden (Ryvarden 1971; Strid 1975; Ingelög et al. 1984), Estonia (Järva, Parmasto 1980), Czech Republic, France, Hungary (J ülich 1984), Ukraina (Zerova et al. 1872), Siberia (Nikolajeva 1961), Russia Far East (Lyubarskij, Vasilieva 1975), India (Jahn, Sturm 1983) and North America in both Canada (Pomerleau 1980) and the USA (Banker 1913; Harrison 1973) (Koski-Kotiranta, Niemelä 1988).

Aknowledgements. I express my thanks and appreciation to Mr Marek Snowarski (Wrocław) for photo taken to fresh fructifications of Gloiodon strigosus and to the Laboratory of Electron and Confocal Microscopy of the Adam Mickiewicz University in Poznań for examing fungus and professional service. 


\section{REFERENCES}

B anker H. 1913. Type studies in the Hydnaceae 6. The genera Creolophus, Echinodontium, Gloiodon and Hydnodon. Mycologia 5: 293-298.

Błoński F. 1889. Spis roślin zarodnikowych zebranych lub zanotowanych w lecie w r. 1888 w puszczach: Białowieskiej, Świsłockiej i Ladzkiej (List of cryptogamic plants collected or noted in summer of 1888 in Primeval Forests: Puszcza Białowieska, Świsłocka and Ladzka). (In:) F. Błoński, K. D ry m m e r (eds). Sprawozdanie z wycieczki botanicznej odbytej do Puszczy Białowieskiej, Ladzkiej i Świsłockiej w 1888 roku (Report of the excursion to Primeval Forests: Puszcza Białowieska, Ladzka and Świsłocka in 1888). Pam. Fizj. 9: 55-115 (in Polish).

Bujakiewicz A. 2002a. New, rare and endangered fungi in the Białowieża Primeval Forest (E Poland). Polish Bot. J. 47 (2): 113-124.

Bujakiewicz A. 2002b. Rhodotus palmatus (Bull.: Fr.) R. Maire. (In:) W. Wojew oda (ed.). Atlas of the geographical distribution of fungi in Poland. 2. W. Szafer Institute of Botany, Polish Academy of Sciences, Kraków: 95-98.

Bujakiewicz A. 2003. Puszcza Białowieska ostoją rzadkich i zagrożonych grzybów wielkoowocnikowych. Parki nar. Rez. przyr. 22 (3): 323-346.

Bu ja ki e wi cz A., Ni t a J. 2004. Żyłkowiec różowawy Rhodotus palmatus (Bull.: Fr.) R. Maire - mieszkaniec białowieskich ostępów. Chrońmy Przyr. Ojcz. 60 (5): 82-85.

Faliński J. B. 1986. Vegetation dynamics in temperate lowland primeval forest. Ecological studies in Białowieża forest. (In:) M. J. A. We rge r (ed.). Geobotany 8, Dr W. Junk Publishers. Dordrecht.

Gin n s J. 1988. New genera and species of lignicolous Aphyllophorales. Mycologia 80 (1): 63-71.

Harrison K. 1973. Aphyllophorales 3. Hydnaceae and Echinodontiaceae. (In:) G. Ainsworth, F. Sparrow, A. Sussman (eds). The fungi, an advanced treatise 4B. A taxonomic review with keys: Basidiomycetes and lower fungi. New York-London: 369-395.

Ingelög T., Th or G., Gu st a f s s o n L. 1984. Floravård i Skogobruket 2. Uddevalla, 408 pp.

J a h H. 1979. Pilze die an Holz wachsen. Herford.

J a h n H., S t u r m Ch. 1983. Der seltene Stachelpilz Gloiodon strigosus (Sw. ex Fr.) P. Karst. in den Alpen gefunden. Westfäl. Pilzbr. 10-11: 209-220.

Järva L., Parmas to E. 1980. Eesti seente kondimestik. Tartu, 331 pp.

Jülich W. 1984. Die Nichtblätterpilze, Gallertpilze und Bauchpilze (Aphyllophorales, Heterobasidiomycetes, Gastromycetes) (In:) H. Gam s (ed.). Kleine Kryptogamenflora. II b/1. Basidiomyceten 1. Fisher Verl., Stuttgart-New York, 626 pp.

Kirk M. P., David P. F., Stalpers J. C. 2001. Ainsworth \& Bisby's Dictionary of the Fungi. 9 th ed. CAB International, Wallinford, $655 \mathrm{pp}$.

Koski-Kotiranta S., Niemelä T. 1988. Hydnaceous fungi of the Hericiaceae, Auriscalpiaceae and Climacodontaceae in northwestern Europe. Karstenia 27: 43-70.

Lyubarskij L., Vasilyeva L. 1975. Drevorazrušayuščie griby Dalnego Vostoka. Novosibirsk,164 pp.

Ma a s Ge e st e r a nu s R.A. 1963. Hyphal structures in Hydnums II. Proc. Kon. Nederl. Akad. Wetensch. (ser. C) 66: 426-457.

Nikolajeva T. 1961. Ežovikovye griby. (In:) V. S a vič (ed.). Flora sporovych rastenij SSSR 6 (Griby 2). Moskva \& Leningrad, 443 pp.

Pome rle a u R. 1980. Flore des champions an Quebéc et regions limitrophes. Montréal, 652 pp.

Rym a n S., Holmås e n I. 1984. Svampar, en fälthandbok. Stockholm, 718 pp.

Ryvarden L. 1971. Studies in the Aphyllophorales of Firnmark, northern Norway. Rep. Kevo. Subarctic Res. Sta. 8: 148-154.

Strid Å. 1975. Wood - inhabiting fungi of alder forests in North-Central Scandinavia. 1. Aphyllophorales (Basidiomycetes). Taxonomy, ecology and distribution. Wahlenbergia 1: 1-237.

Wojewoda W. 2003. Checklist of Polish larger Basidiomycetes. (In:) Z. Mirek (ed.). Biodiversity of Poland. 7. W. Szafer Institute od Botany, Polish Academy of Sciences, Kraków, 812 pp.

Wojewoda W., Ławrynowicz M. 2006. Red list of the macrofungi in Poland. Czerwona lista grzybów wielkoowocnikowych w Polsce. (In:) Z. Mirek, K. Zarzycki, W. Wojewoda, Z. Szeląg (eds). Red list of plants and fungi in Poland. Czerwona lista roślin i grzybów Polski. W. Szafer Institute of Botany, Polish Academy of Sciences, Kraków: 53-70.

Zerova M., Radzievskij G., Š e rčen ko S. 1972. Viznačnik gribiv Ukrajni. 5. Basidiomiceti 1, ekzobasidialni, afilofaralni, kantarelalni. Kijv, 240 pp. 
Gloiodon strigosus (Swartz: Fr.) P. Karst. (Bondarzewiaceae) w Polsce

Streszczenie

Przedstawiono opis stanowiska, synonimikę i ikonografię Gloiodon strigosus, gatunku uważanego za wymarły w Polsce. Podano też uwagi dotyczące ekologii i chorologii gatunku. Gloiodon strigosus jest gatunkiem wskaźnikowym dobrze zachowanych borealnych lasów łęgowych. 

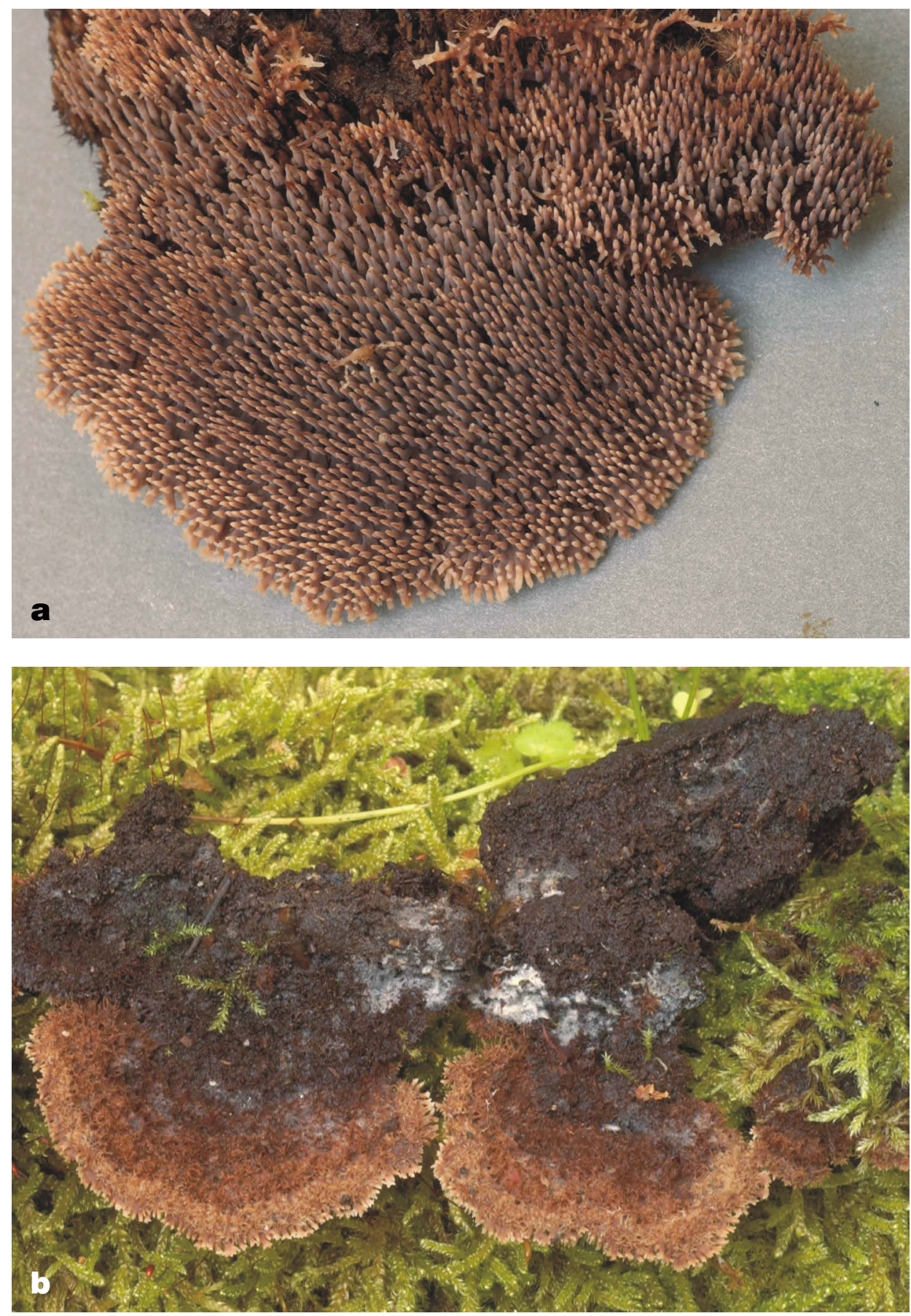

Fig. 2. Fructifications of Gloiodon strigosus: a) hymenophore with spines; b) upper surface covered with soft hairs. Phot. M. Snowarski. 


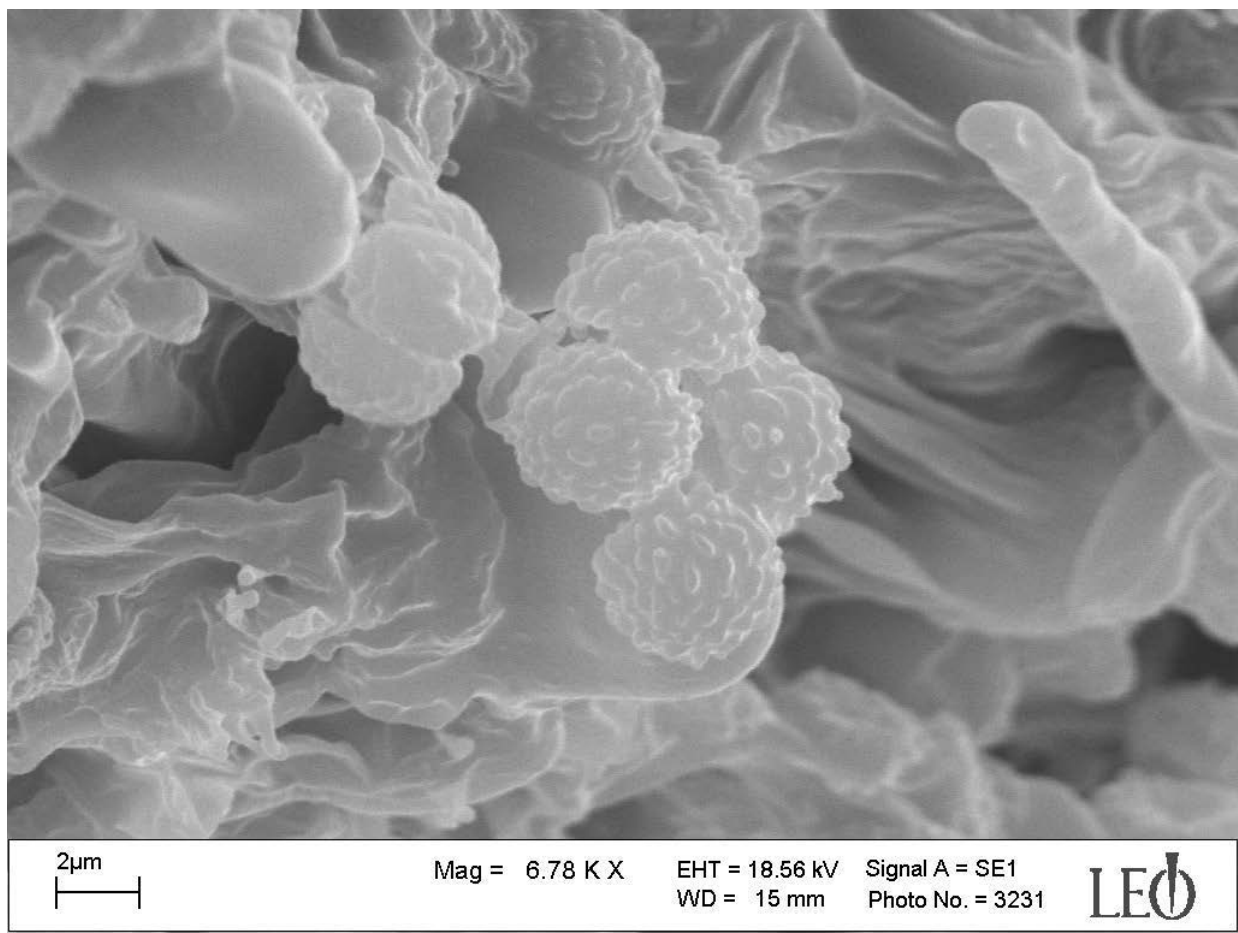

Fig. 3. Minutely verrucose spores of Gloiodon strigosus (SEM x 6,78 KX) (Courtesy of Lab. Electron \& Confocal Microscopy, Adam Mickiewicz University, Poznań). 